\title{
Designing green taxes in a political context: From optimal to feasible environmental regulation
}

\author{
Carsten Daugbjerg \\ Gert Tinggaard Svendsen*
}

\begin{abstract}
SUMMARY
How should green taxation be designed so that it accommodates producer interests? We argue that to design green taxes which are high enough to have the desired incentive effects, tax revenues must be reimbursed, either by earmarking them for environmental subsidies or by reducing other taxes directed at industry. If green tax schemes can be designed this way, industry will have little incentive to mobilise strong opposition to green taxation. However, in practice, the requirement of reimbursement may be difficult to fulfil because, with few exceptions, polluting industries are not homogeneous. This means that reimbursement will redistribute financial resources within industry and thus create winners and losers. Still, green taxes can be used in heterogeneous industries which can be created by operating separate tax schemes for each branch of industry. The Danish case of pesticide taxation demonstrates that relatively high tax levels can be implemented if an equal relationship between the tax object and the object determining the level of refunds exists throughout the sector. This means that revenues can be reimbursed without creating redistribution within producer communities.
\end{abstract}

JEL Classification: Q28, H2, H4

Keywords: green taxation, policy design, reimbursement, lobbyism, redistribution.

\section{Acknowledgements}

We gratefully appreciate the financial support from CESAM, University of Aarhus, and the Danish Ministry of Energy (EFP98). Previous versions were presented at the $5^{\text {th }}$ Nordic Environmental Research Conference: The Ecological Modernisation of Society, 14-16 June 2001, Aarhus University and at a paper session in the Public Policy Division, Department of Political Science, Aarhus University. We are grateful for the participants' comments. Special thanks also goes to Anders Branth Pedersen, and Martin Paldam, Aarhus University; Lene Hjøllund, Tor Eriksson, Hans Linderoth, Erik Stroejer Madsen and Ann-Marie Gabel, Aarhus School of Business. Needless to say, the authors alone are responsible for the content.

\footnotetext{
*Author to whom correspondence should be sent:

Gert Tinggaard Svendsen, Associate professor, PhD, Department of Economics, The Aarhus School of Business, gts@hha.dk, http://www.hha.dk/eok/nat/staff/gts form.htm
} 


\section{1: Introduction}

Traditionally, pollution in Western Europe has been regulated by the use of standards (the command-and-control approach). It tends 'to force all businesses to adopt the same measures and practices of pollution control and thus accept identical shares of the pollution control burden regardless of their relative impacts' (Andersen, 1994, p. 21). Among environmental researchers and policy makers, there is a growing scepticism towards this type of pollution control. It is argued that environmental improvement is progressing too slowly and, in some situations, is leading to even further deterioration of the environment.

Therefore, policy makers search for other solutions. In particular, there is a growing interest in market-based environmental policy instruments such as green taxation. Throughout Europe, academics and policy makers are vigorously discussing this option.

Still, the level of green taxation in Europe is set too low to have the desired effect on environmental behaviour. Thus, Howe (1994) concludes that the main effect of green taxation is fiscal rather than environmental. For example, green taxation has been applied in relation to the reduction of carbon dioxide $\left(\mathrm{CO}_{2}\right)$ emissions in OECD countries. However, one may argue that even though $\mathrm{CO}_{2}$ taxes are differentiated, they may lead to the required environmental results. A straightforward way of measuring these environmental results is simply to look at the nominal emission development in the five OECD countries where $\mathrm{CO}_{2}$ taxes so far have been applied: see Table 1 below. 
Table 1 Total $\mathrm{CO}_{2}$ emissions in countries with $\mathrm{CO}_{2}$ taxation from $1990-1997$

\begin{tabular}{lllll}
\hline & $\mathrm{CO}_{2}$ tax, year & 1990 & 1997 & Increase 1990-97 \\
\hline Denmark & $1992-93$ & 53 & 63 & $19 \%$ \\
Sweden & 1990 & 55 & 57 & $4 \%$ \\
Norway & 1991 & 35 & 41 & $17 \%$ \\
Finland & 1990 & 73 & 77 & $5 \%$ \\
Netherlands & 1990 & 160 & 179 & $12 \%$ \\
\hline
\end{tabular}

Note: Figures are rounded to the nearest million ton.

Source: Daugbjerg and Svendsen (2001) and Andersen, Dengsøe and Pedersen (2001).

Note, that Table 1 uses nominal $\mathrm{CO}_{2}$ emission figures and the year 1990 as reference year because these two criteria are used in the Kyoto Protocol which is an international agreement on national $\mathrm{CO}_{2}$ target levels (see Daugbjerg and Svendsen, 2001, Chapter 6). Table 1 shows that $\mathrm{CO}_{2}$ emissions have increased significantly since 1990 for all five countries that have applied $\mathrm{CO}_{2}$ taxation. As shown, the $\mathrm{CO}_{2}$ taxes were all introduced in the beginning of the 1990's.

E.g. Denmark's total $\mathrm{CO}_{2}$ emissions have increased from 53 million tons in 1990 to 63 million tons in 1997 (19per cent) and Norway's total $\mathrm{CO}_{2}$ emissions have increased from 35 million tons in 1990 to 41 million tons (17per cent). So, in general, $\mathrm{CO}_{2}$ taxation has not succeeded in cutting actual emissions in order to achieve the stated target levels such as those found in the Kyoto Protocol.

The numbers in Table 2 provide simple and strong evidence and do, of course, cover much detail which we have chosen to leave out in this setting. E.g., choosing 1990 as the starting year in the Kyoto Protocol is not favourable to Denmark. 1990 was a wet year in Norway and therefore, Denmark imported much Norwegian hydropower that year implying low starting figures. In other years Denmark is typically a net exporter of coal produced electricity (Varming et al., 2000, 199). Still, Denmark signed the 
Kyoto Protocol thus accepting the use of nominal emission figures rather than figures corrected for imports and exports of electricity.

Because emissions have increased rather than decreased, we see a strong need to undertake an analysis of the politics of green taxation to reveal why this policy instrument may not work as intended. At first sight, this is puzzling because we would expect polluting industries to prefer green taxes to traditional command-and-control regulations (e.g. standards) for at least two reasons. Firstly, environmental economists have demonstrated that green taxes involve less economic costs to society than standards (e.g. Baumol and Oates, 1971; 1988). Secondly, the use of taxes allows individual industrial producers greater flexibility than regulations in achieving pollution reduction (OECD, 1997, 9). Green taxes leave individual producers free to decide how to reduce pollution, whereas regulations tend to specify which actions must be taken.

In general, environmental economists have paid no, or at best very little, attention to the political context within which green taxation would be introduced (Daugbjerg and Svendsen, 2001). In the development of environmental policy instruments which have a realistic chance of being implemented, the political constraints and opportunities must be taken into account. An important constraint is the ability of industrial associations succesfully to oppose environmental measures which they find too burdensome. This political power of industry cannot be neglected.. This raises the following question: how should green taxes be designed so that they accommodates industrial interests without neutralizing their effectiveness? It is argued here that it is important to combine them with reimbursement schemes which do not redistribute economic resources within industry.

Green taxation does have a certain potential in environmental regulation which can be utilised in the future though it is not a universal measure which can be successfully applied in all situations. This requires that policy designers give higher priority to the political dimension of the instrument. Several researchers have argued that the choice of instruments is a political process and not a matter of finding the or those instrument(s) which best fulfil the objectives of a policy (e.g. Daugbjerg 1995, 1998a, 1998b, 1998c, 1999; Doern and Phidd 1983, Hood 1983, Howlett and Ramesh 1994, 
Linder and Peters 1989; Majone 1989, Salamon 1981, 265). Elmore (1987, 175) suggests that the choice of policy instruments 'has more to do with coalition politics than with their operating characteristics'. Ultimately, instruments are chosen because they are able to generate the necessary political support, Still, the discipline of environmental economics has not moved in the direction of political economy in spite of the early advice to do so by Buchanan and Tullock. Already in 1975, they concluded that to make green taxation more attractive to policy makers, economists should 'begin to search out and invent institutional arrangements that will make the penalty tax acceptable to those who are primarily affected' (Buchanan and Tullock, 1975, 147).

The real challenge for both social science environmental research and environmental policy makers is to combine economic efficiency and political acceptability. Simple theoretical outlining is important because the reality of environmental regulation is extremely complex. Here, the principle of Ochams' razor is truly needed: any inessential premises or complexities ought to be cut out of an argument. Hence, in an attempt to suggest simple and forceful propositions, we attempt to meet the challenge by suggesting some ways to design green tax schemes which will help to overcome the political opposition identified in our analysis of real-life green tax policy making.

In Section 2, it is discussed how green tax schemes can be constructed in order to make them more politically acceptable to industry. Section 3 presents empirical evidence concerning reimbursement schemes for CO2 taxation in Denmark, Norway and Sweden. Subsequently, reimbursement of tax revenues and the problem of redistribution is discussed in Section 4. Finally, the limitations and opportunities concerning future use of green taxation are summarised in Section 5. 


\section{2: Making green taxation politically acceptable}

Environmental regulation produces costs and benefits as do other types of regulatory policy (see Leone, 1986, 3). Pollution control distributes cost and benefits in various ways. The most difficult type of pollution control occurs when regulation concentrates the costs of implementing policy on a well-defined group of polluters and the benefits of policy are dispersed. For instance, reduction of air pollution, , is costly to industry (unless it is compensated for the costs incurred) because it has to pay for the installation of equipment to combat pollution. These costs may be difficult to pass on to consumers. The benefits are dispersed both in space and time. Environmental improvement is widely dispersed to a large group of persons (e.g. the public at large) in which each member is only affected at the margin. Furthermore, environmental improvement may also involve a time dimension as it may affect future generations positively.

This distribution of policy costs and benefits means that industry has strong incentives to organise opposition to the introduction of burdensome environmental policies because each of them has a lot to win if political action bears fruit. In other words, it pays off to contribute to collective action. Those benefiting from pollution control do not have similar incentives to enter the policy process. Since benefits are widely dispersed, each member of the benefiting group has little to win and therefore little motivation to invest resources (such as time and money) in organising, or mobilising political support, for environmental regulation. Such a distribution of costs and benefits means that environmental politics becomes the politics of cost distribution. Typically, this type of environmental politics can be found in economic sectors, such as industry and agriculture. The politics of green taxation can be characterised the same way.

Many environmental economists argue that green taxes limit pollution at something which approximates minimum costs to society - if properly designed and implemented (e.g. Baumol and Oates, 1988, 155; Pearce and Turner, 1990, 94-6; Pearce et al., 1989, 155). Clearly, societal efficiency concerns is the central economic 
argument behind this statement. However, taxation may be more costly to polluters than regulation. Hence, they strongly oppose this type of environmental regulation.

The use of environmental taxation is an efficient way of undertaking pollution control from a macro-economic perspective. However, if tax revenues are not refunded to polluters, taxation is more costly to them than regulation. This may be clarified by a hypothetical example. Assume that we have two polluting firms; Firm 1 and Firm 2. As shown in Figure 1 below, Firm 2 has smaller reduction costs $\left(M C_{2}\right)$ than Firm 1 $\left(M C_{l}\right)$.

Figure 1: Societal and private costs following a standard and a tax.

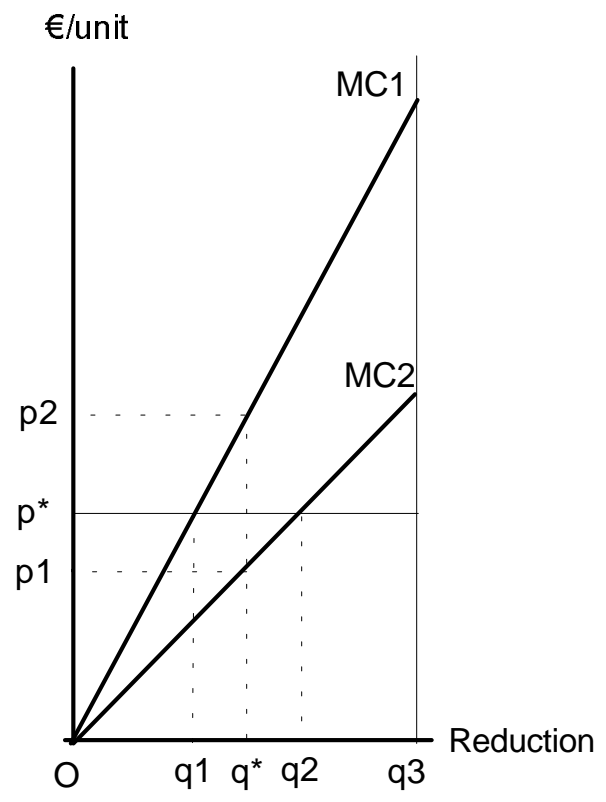


Environmental authorities can use a standard or a tax to achieve the objective of reaching the $q^{*}$ target level. A standard would require each polluter to reduce the emissions by $q^{*}$. However, this approach may be an expensive way to reduce pollution because, at existing levels of output, the marginal cost of reducing emissions for Firm 2 is smaller than the marginal cost for Firm 1. Therefore, we would expect it to be much cheaper for the economy as a whole to assign Firm 2 a greater reduction in emissions. This can be done by a tax set at $p^{*}$. A tax would motivate Firm 2 to reduce its emissions much more than Firm 1, and thus pollution would be reduced at the lowest economic cost (see Baumol and Oates, 1988, 164).

To society as a whole, the tax option is the cheapest option as illustrated by the following hypothetical comparison of the costs associated with the two types of policy instruments. Say, that $q_{1}$ is 2 units, $q^{*}$ is 3 units and $q_{2}$ is 4 units of reduction. Say, furthermore, that $p_{1}$ is $3 € /$ unit, $p^{*}$ is $4 € /$ unit and $p_{2}$ is $6 € /$ unit. Then we get the following results. If both firms face the same standard, $q^{*}$, corresponding to 6 units of reduction in total, then reduction costs sum up to $€ 13$. . $^{1}$

On the other hand, if both firms face the optimal tax $p^{*}$, total reduction costs are $€ 12$. $^{2}$ This means that society saves $€ 1.5$ when using green taxation compared with a standard. In this way, a tax, $p^{*}$, would motivate Firm 2 to reduce its emissions more than Firm 1, and thus pollution would be reduced at the lowest economic cost. Firm 1 and Firm 2 will cut back emissions 'until the marginal cost of further reductions in smoke output is equal to the tax' (Baumol and Oates, 1971, 46). So, green taxation is economically more efficient than a standard from society's point of view.

However, this does not necessarily mean that taxation is better than a standard from polluters' point of view. If tax revenues are not reimbursed, regulation by standards will be cheaper for industry than regulation by taxation (see Buchanan and Tullock, 1975). Take a further look at Figure 1 and let us say that $q_{3}$ corresponds to a 100 per cent reduction (no emission) equal to 6 units. A tax without refund means that on top of the reduction costs from reducing $q_{1}$, Firm 1 must pay taxes for all units emitted, i.e. the rectangle $\left(q_{3}-q_{1}\right) p^{*}$. This extra tax payment of $€ 16$ together with the $€ 4$ in

\footnotetext{
${ }^{1}$ Firm $1: 1 / 2 \times 6 \times 3=9$; Firm $2: 1 / 2 \times 3 \times 3=4.5$

${ }^{2}$ Firm 1: $1 / 2 \times 4$ x $2=4$; Firm 2: $1 / 2 \times 4$ x $4=8$
} 
private reduction costs, means a total cost of $€ 20$ from green taxation without refund, compared with a total cost of $€ 9$ from a standard. Likewise, Firm 2 will face the extra tax payment costs of the rectangle $\left(q_{3}-q_{2}\right) p^{*}$. This extra cost of $€ 8$ added to the private reduction costs of $€ 8$ totals $€ 16$ which is significantly higher than the $€ 4.5$ following standard regulation.

Basing our proposition on this numerical example, we expect industry actively to pursue their interests in the political processes in which green tax schemes are designed. Moreover, given the distributional effects of environmental regulation, we also expect them to be fairly successful in influencing the policy design due to smallgroup advantages. It is easier for industrial producers to lobby due to group size than it is for e.g. the large group of households, see Olson (1965) and Svendsen (1998).

\section{3: The politics of green taxation in Scandinavia}

\section{1: Method}

We will now take a closer look at the empirical evidence to establish whether industrial groups more actively pursue their interest in the environmental policy process than do households and are more influential than them in affecting policy contents. We have chosen to focus on $\mathrm{CO}_{2}$ taxation in Denmark, Norway and Sweden. So far, only Denmark, Norway, Sweden, Finland and the Netherlands have applied such taxes. There are three main reasons for focusing on Denmark, Norway and Sweden and omitting Finland and the Netherlands. First, these three Scandinavian countries have $\mathrm{CO}_{2}$ taxes which are levied through a separate self-contained tax scheme. In Finland and the Netherlands, the use of $\mathrm{CO}_{2}$ taxes takes place in connection with a more general energy tax where the $\mathrm{CO}_{2}$ component constitutes only a part of the tax base (Svendsen et al., 2001). Second, an extraordinary openness has made it possible to follow the development in decision-making in these three countries. Written documents cover the whole process. Third, the three Scandinavian countries represent a homogeneous group having fairly similar political and 
administrative institutions. Most prominently, they are characterised by a high degree of corporatism: 'The integration of organised interests into public and administrative policy making is a core political structure of the Scandinavian countries.' (Christiansen, 1997, 3).

Three appropriate cases for testing and comparing the effect of lobbyism are Denmark, Norway and Sweden because the $\mathrm{CO}_{2}$ emission in question, has global effect (ibid.). This means that no local or regional pollution effects can explain differences in the way $\mathrm{CO}_{2}$ is taxed. For each of the three cases, we have applied a two-phased approach. First, we reveal industrial interest groups' presence in the policy making process, measured by their active opposition (i.e. activities in the media, contacts with government, published reports and statistical data, brochures, etc.). These activities are used as an indicator of their effort in the decision-making process. Second, we assess the effects of this effort. This is done by analysing the development of actual $\mathrm{CO}_{2}$ tax designs over time. In each of the three countries, we chose the same approach by focusing on two cases in each country, namely the introduction of a initial $\mathrm{CO}_{2}$ tax and the first major attempt to reform it.

\section{2: Findings}

Our data shows that in the three Scandinavian countries, the massive presence of industrial groups (measured by their active opposition, i.e. activities in the media, contacts with government, published reports and statistical data, brochures, etc.) was overwhelming compared to that of households. Thus, overall, the development of $\mathrm{CO}_{2}$ taxation and later reforms supported the hypothesis that industry achieved their results by lobbyism. Industry, in contrast to households, was active when the instruments were designed to determine the outcome of the crucial issue of cost distribution of $\mathrm{CO}_{2}$ reduction costs. Let us briefly summarize the empirical findings in Daugbjerg and Svendsen (2001) concerning Denmark, Norway and Sweden.

In Denmark, a national $\mathrm{CO}_{2}$ target level was introduced in 1990. It stated that Denmark should reduce its $\mathrm{CO}_{2}$ emissions by 20 per cent from 1988 to year 2005 
(Energiministeriet, 1990, 91). This target level was settled at a conference in 1989 convened by the Danish Ministry of Energy (Folden et al., 1993, 53). In Denmark, industry reacted aggressively and they became the winners compared to the consumers who were by far the most heavily taxed group. The tax levels in the original Danish $\mathrm{CO}_{2}$ tax proposal were significantly lowered for industry during the political decision-making process and also the final bill referred to earlier included a system of generous voluntary agreements that industry asked for. This pattern was repeated, in the political decision-making process concerning the reform of $\mathrm{CO}_{2}$ tax (in 1995) being similar to that of the original $\mathrm{CO}_{2}$ tax (in 1991); here, environmentalists and consumer organisations had been represented in the initial phases but not in the final and decisive ones concerning instrument choice (Daugbjerg and Svendsen, 2001).

The background for introducing $\mathrm{CO}_{2}$ taxation in Norway was the appointment of two commissions in 1989, namely the Climate Group and the MU Commission ('Miljøafgiftsudvalget'). The recommendations of the two commissions formed the basis of the government proposal to let $\mathrm{CO}_{2}$ taxation to embrace industry and energy production (Tenfjord, 1995, 94-5). In Norway, industry dominated the political arena too and it was favoured by either no or lower $\mathrm{CO}_{2}$ taxes compared to households. Exemptions for industry were already a fact in Norway when designing the initial $\mathrm{CO}_{2}$ tax. Consumer interests were again, like in Denmark, almost absent after taking part in establishing an initial target level. Discussions on instruments and $\mathrm{CO}_{2}$ cost distribution in practice, among different sectors in society, left no room for consumer interests in the domestic decision-making process. Also, when a new Norwegian Green Tax Commission suggested that exempted industries should be taxed and government tried to enact it, the proposal was successfully blocked by industry (Daugbjerg and Svendsen, 2001).

Sweden, like Denmark and Norway, established a national target level in the late 1980s. In 1988, the government stated its ambition of stabilizing $\mathrm{CO}_{2}$ emissions at the 1988 level (SOU 1989, 271). Beforehand, in 1987, the government had appointed a Green Tax Commission (Lundqvist, 1996, 314; Naturvårdsverket, 1997, 16). On the recommendation of the Green Tax Commission, a non-differentiated $\mathrm{CO}_{2}$ tax was imposed in January 1991 on industry (Swedish Government, 1990, 147-64). This 
initiated aggressive campaigning from Swedish industry resulting in a 1993 reform, where a new $\mathrm{CO}_{2}$ tax favoured manufacturing industry but punished the households. Thus, from early 1991, the trend corresponded exactly to the pattern observed in Denmark and Norway. In this way, lobbyism successfully turned unfavourable uniform taxation into politically acceptable differentiated $\mathrm{CO}_{2}$ taxation (Daugbjerg and Svendsen, 2001).

This brief comparison of three Scandinavian cases of $\mathrm{CO}_{2}$ taxation confirms the hypothesis that industry has strong incentives to enter the policy process and have resources, and thus power, to influence policy contents to decrease costs. Clearly, the Scandinavian governments have been persuaded by industrial interest organisations to tax industry at a lower rate than households. When sectors that pollute the most are not taxed, pollution reduction does not take place in an optimal way. The original policy recommendation by Pigou (1920) is still valid in year 2000: an efficient environmental tax rate must be imposed directly on emissions and the tax rate must be uniform per emission unit.

The existence of such a uniform environmental tax means that firms will reduce emissions up to the point where the marginal cost of reducing one extra pollution unit equals the tax rate. Therefore, it costs the same to reduce the last pollution unit in all firms. If the tax rate is not uniform, different polluters would face different tax levels. For example, producers facing low tax levels would stop reducing at the same low marginal cost level whereas consumers facing high tax levels would keep on reducing until their marginal reduction costs became high enough to match the tax rate level. In other words, because it is cheaper for producers than for consumers to reduce an extra pollution unit, society would be better off if producers reduced more and consumers less. This would lead to a lowering in the total reduction cost. As long as tax rates are not uniform, society can save costs by shifting pollution reductions from the hightaxed to the low-taxed polluter. Only when all polluters face the same tax level, will the optimal situation be achieved, where all marginal reduction costs are identical for all polluters. It will no longer be possible to save costs by shifting pollution reduction between, for example, producers and consumers. 
The overall finding is that political decision-makers must, with respect to industry, modify the current design of green taxation into a more politically feasible solution, for example by considering the use of tax reimbursement schemes as we do here or by considering other economic instruments such as tradable permit systems (concerning tradable permit systems, see e.g. Tietenberg, 1985; , Svendsen, 1998 and Daugbjerg and Svendsen, 2001, ch. 6); Boom and Svendsen, 2000 and Klaassen and Nentjes, 1997).

\section{4: The problem of redistributive reimbursement}

Our numerical example in section 2 clearly demonstrated that reimbursement of green tax revenues is a crucial measure to make green taxation more acceptable to producer groups and thus decrease political opposition. Two basic requirements must be fulfilled to make green taxation acceptable to environmental interests and industry. First, to ensure that reimbursement does not neutralise the environmental incentives of the tax scheme, it must be independent of the level of pollution, otherwise the incentive to reduce pollution would be removed. For instance, it would not matter to the polluter how much s/he discharged or emitted if all of the money paid in taxes would be refunded. Second, reimbursement should not redistribute financial resources within the producer community subject to the tax. Redistribution within producer communities create winners and losers. This is likely to bring about mobilisation of opposition among losers, while potential winners have weaker incentives to mobilise for gains. However, redistributive green tax schemes are indeed applied. As long as the tax level is relatively low and the redistribution, caused by reimbursement, is limited, it may not bring about significant opposition. The problems of redistribution and opposition within producer groups increase with higher tax levels. Environmental policy makers may thus be caught in a unpleasant situation if they want to continue using green taxation as the major environmental regulatory instrument because to reach the stated reduction goals, higher tax levels are needed.

Potential losers from green taxation are more likely to mobilise politically than potential winners. As Weaver $(1986,373)$ points out: "persons who have suffered losses are more likely to notice the loss, to feel aggrieved and to act on this grievance, 
than gainers are to act on the basis on their improved state.' In other words, people 'are more sensitive to what has ... [been] done to them than what has been done for them' (bid.). Experiments have shown that people feel more affected by losses than by gains (Thaler, 1980; Kahnemann and Tversky, 1979; Knetsch, 1990; Kahneman, Knetsch and Thaler, 1991). This means that losers have much better opportunities to mobilise than winners when redistributive policies are put onto the political agenda. Hence, it is crucial not to create losers when designing green taxes with reimbursement schemes. The trick is to develop refund schemes which do not redistribute. Some scholars are rather pessimistic about this. For instance, Leone $(1986,3)$ argues that 'every act of government, no matter what its broader merits or demerits for society at large, creates winners and losers within the competitive sector of the economy. These gains and losses, which accrue to both individuals and corporations, become the object of intense political attention.' Our analysis supports Leone's argument to some extent, but we shall argue that in certain situations, reimbursement can take place without causing significant redistribution.

It is important to distinguish between earmarked and non-earmarked reimbursement (Daugbjerg, 1998c). In the ear-marked approach, revenue is paid back as various types of environmental subsidies. To qualify for reimbursement, industrial producers are obliged to engage in environmentally friendly activities. Earmarked reimbursement may redistribute financial resources within producer communities, but the scheme is open to all producers. As a result, they have the opportunity to benefit from environmental subsidies, provided that they engage in certain environmentally friendly activities such as introducing cleaner production technologies or not farming in environmentally sensitive areas. In the non-earmarking approach, the revenue is refunded irrespective of whether industry engages in certain environmentally friendly activities or not. Proceeds are reimbursed automatically, e.g. through direct subsidies or through reductions of existing taxes. Members of the industry concerned are not obliged to do certain things to qualify for refunds. This means that industry tends to prefer non-earmarked reimbursement. However, these schemes are difficult to design because may easily redistribute economic resources within producer communities. This becomes a political problem since the individual producer cannot escape redistribution by engaging in certain environmentally friendly activities as s/he can in earmarked reimbursement. Thus, redistribution is not a choice, but a fact. To 
demonstrate this problem, we analyse two models of non-earmarked reimbursement which are frequently suggest in the literature on green taxation and, to a limited extent, has been applied in. These are reduced taxes linked to employment of labour and reduced corporate tax.

\section{1: Labour taxes}

Within the industrial sector, reimbursement through reduced income taxes (which is assumed to bring about lower wages) or reduced employer contributions to labour market services or social security, will inevitably bring about winners and losers among firms. An important source of redistribution is the extent to which enterprises employ labour and capital, for example, energy. Labour-intensive industries will benefit from reduction in labour costs, whereas energy-intensive industries are likely to lose. The Dutch tax on $\mathrm{CO}_{2}$ is an example of a green tax scheme causing redistribution through reimbursement by the reduction of tax contributions to labour market services. One of the winners is the financial sector and one of the losers is the food processing industry (VROM, 1998). The basic problem of reimbursement through reduced labour costs is that energy-intensive industries will oppose green taxation because each of them are likely to pay more in tax than they are likely to get back since the benefits are linked to the employment of labour. In other words, they are potential losers, and thus they have strong incentives to mobilise political opposition. Labour-intensive industries are potential winners, but may fail to lobby for a taxation and refund system because their incentives to mobilise politically are weaker. The Norwegian government's failed attempt to broaden the $\mathrm{CO}_{2}$ tax is a powerful example supporting this theoretical argument. Revenues were to be refunded through reduced employer contributions to labour market services which meant that the energy-intensive industries in particular (mainly pulp and paper, chemical, metallurgical and oil industries) would lose out. Therefore, they had strong incentives to oppose the tax scheme, which they did successfully. The potential winners were the labour-intensive retail sector and service industries. In line with the theoretical argument, these two sectors, as potential winners, did little to support the government proposal, whereas the energy-intensive industries, as potential losers, put considerable effort into opposing the tax and eventually succeeded in having the proposal voted 
down in parliament (Kasa, 1999; Svendsen et al., 2001). Given these incentive structures, it is difficult to impose a tax high enough to create noticeable incentive effects. Redistribution can only be avoided if there is a fairly equal relationship between emissions and employment of labour throughout the sector concerned.

\section{2: Corporate tax}

Corporate tax reductions also involve redistribution within producer communities. Firms which have high profits benefit more from lower company taxes than those which earn less money because there is no linear relationship between the level of earnings and the level of emissions. Thus, the side effect of corporate tax reductions is redistribution of financial resources from prosperous to less prosperous firms. Redistribution can only be avoided in industries with a fairly equal relationship between profits and emissions. These are hard to find in the real world.

\section{5: The future of green taxation and reimbursement in industrial sectors}

This paper has demonstrated that polluters prefer traditional command-and-control (i.e. standards) rather than green taxation without refund. In spite of the fact that green taxation is the cheapest solution for society as a whole, the polluter will still experience lower private costs when facing a standard without the added costs of tax payments. Therefore, proposals on green taxation are likely to meet strong opposition from industrial interest groups and they can easily mobilise resources to influence policy contents. Since similar incentives to enter the policy process cannot be found within consumer and environmental groups, industry is like to have considerable say on the design of green tax schemes. Empirical evidence from $\mathrm{CO}_{2}$ taxation in Denmark, Norway and Sweden support this theoretical expectation. We have argued that there are ways to overcome the opposition to green taxation. The opportunities 
are embodied in the design of the tax schemes. In particular, it is important that tax revenues should be reimbursed. However, although policy makers follow these recommendations, there may still be major obstacles to the use of green taxation in economic sectors because reimbursement schemes may redistribute within producer communities, thus creating winners and losers.

Our analysis of two reimbursement models demonstrates clearly that they cause redistribution and, therefore, are not attractive to industrial interest groups. Since people are more sensitive to losses than gains, losers are more likely to mobilise politically than winners. In other words, both reimbursement models are likely to cause asymmetry in interest mobilisation in favour of those opposing green taxation. The analysis also shows that in heterogeneous sectors, it is difficult to develop green tax schemes which reimburse revenues without bringing about winners and losers within producer communities and, at the same time, avoid neutralising the incentives to reduce emissions.

The models discussed are fairly simple and do not require availability of considerable administrative resources to be implemented. Of course, more sophisticated reimbursement models may redistribute to a lesser degree than the simple models discussed. However, in practice, such schemes may be troublesome to design and administer. First, it might be difficult to ensure that reimbursement schemes do not neutralise the incentive effects. Second, to avoid redistribution, they may have to be very complex, which in turn means that they may be difficult to administer for bodies responsible for implementation of the schemes. Further, these administrative difficulties may increase the risk of mismanagement and perhaps fraud. Third, complex reimbursement models have a high risk of causing unintended consequences. For example, the Danish $\mathrm{CO}_{2}$ tax scheme has a complicated refund system which turned out to produce perverse incentives. It motivated the Confederation of Danish Industries to encourage its members to increase their $\mathrm{CO}_{2}$ emissions to receive higher refunds and thereby save money (CDI, 1992; Daugbjerg and Svendsen, 2001). Finally, unintended redistributive effects may arise because large firms that can afford to employ staff to get as much revenue back as possible may benefit more from reimbursement than those firms which do not have the resources to hire extra 
administrative staff. In other words, complex reimbursement schemes may redistribute from small to large companies, and then we are back to where we started.

To prevent reimbursement schemes resulting in a redistribution within the sectors taxed, we must identify some homogeneous traits within the sector concerned. It is essential that there is an equal relationship between the tax object and the object determining the level of reimbursement throughout the sector. Thus, the more homogeneous the sector, the more opportunities there are to develop reimbursement schemes which do not redistribute within producer communities.

The Danish case of pesticide taxation is an illustrative example of successful reimbursement within an economic sector which is no longer as homogeneous as earlier. Farmers have specialised in the production of one product. Homogeneous traits could be identified and used as the foundation of reimbursement. This meant that the reimbursement schemes caused only minor redistribution within the farming community.

In 1995, the Danish government introduced a pesticide tax which, compared with those of the other Scandinavian countries, was set at a high level. The tax on insecticides was equal to 37 percent of the retail price and on fungicides, herbicides and crop growth-regulating chemicals, it was equal to 15 percent (Daugbjerg and Svendsen, 2001). The introduction of such a tax demonstrates that when reimbursement schemes are carefully designed in order to limit redistribution, green taxes can be set at a high level even in sectors in which producers are powerful. The tax revenue is reimbursed by the suspension of the state land tax. In this way, reimbursement is independent of the amount of pesticides used. As pointed out above this is an important prerequisite ensuring that the incentive to reduce pesticide use is not neutralised by reimbursement.

As argued above, minimisation of redistribution within producer communities resulting from reimbursement is crucial obtaining acceptance of green taxation. The Danish pesticide tax scheme minimises redistribution because a positive correlation between land values and pesticide use exists. The reason that this relationship existed was that the most pesticide demanding crops were grown at the good and expensive 
soil, and therefore farmers owing this type of land would pay most money in pesticide taxes. Since farmers in these areas paid a larger amount in land taxes due to high land values, they would get a larger amount reimbursed by the suspension of the state land tax than those farming the land of lower soil quality and therefore lower land value. However, minor redistrubution could not be avoided. While the overall redistribution between dairy, pig and arable farmers was minimal, regional differences occurred. The great losers, farmers in the county of Bornholm, would lose 38 Danish kroner per hectare because of low land values. The winners would be farmers in the rural areas close to Copenhagen. They would win 52 kroner per hectare. Furthermore, small farms would gain 14 kroner per hectare, while the largest ones would only lose 7. (Skatteministeren 1995). ${ }^{3}$ During the preparation of the proposal, substantial work was done to develop the reimbursement scheme and estimating its effects on the distribution of income. Both the Farmers Union and the Ministry of Agriculture was engaged in this work (interview, Ministry of Food, Agriculture and Fisheries, 2000).

The fact that the reimbursement scheme involved only minor redistribution within the farming community is an important reason why the Danish government succeeded in introducing a relatively high pesticide tax in 1995. This type of reimbursement did not generate winners and losers among farmers, and therefore the farmers' unions accepted the pesticide tax (Daugbjerg, 2001). In 1998, the government doubled the pesticide tax and adopted a reimbursement scheme which redistributed from conventional farms to organic farms. This was opposed by the losers within the farmers' union, and within half a year they succeeded in persuading politicians to reduce local land taxes to diminish redistribution (Daugbjerg and Svendsen, 2001).

Within the industrial sector, the idea of reimbursement is much more problematic because the sector, as a whole, is considerably more heterogeneous than the agricultural sector. This means that it may be difficult to identify some common traits across the sector which can become the foundations of reimbursements. Industry-wide reimbursement will inevitably bring about winners and losers and, as a result, considerable opposition to green taxation.

\footnotetext{
${ }^{3}$ However, horticulture would lose income and, therefore, special measures were put into operation to ensure that it was not undercompensated (Skatteministeren 1995).
} 
In some situations, it may be possible to subdivide the industrial sector into fairly homogeneous branches. Then, opportunities for operating relatively simple reimbursement schemes for each branch which do not redistribute within the industrial branch concerned may arise. This approach has not yet been applied in green taxation; however, there is no reason why it could not be done. In the Netherlands, a voluntary agreement for each industrial branch is a major policy instrument in environmental regulation. By year 2000, 29 agreements had been made (Enevoldsen, 2000, 73). If a branch approach can be operated in relation to voluntary agreements, why shouldn't it be manageable in relation to green taxes with reimbursement schemes? Such specific reimbursement models have not yet been developed. The two general models (reduced taxes linked to employment of labour and reduced corporate taxes) discussed above are not applicable as reimbursement models in industrial branches because they will also redistribute at this level. New models must be developed. This is the future challenge to the advocates of green taxation if this approach in environmental regulation is to bring about the environmental reduction targets set out. As shown in the introduction to this article, so far the tax approach has failed to reduce $\mathrm{CO}_{2}$ emissions to the level desired. Higher taxes are required to bring about reductions; however, unless non-redistributive reimbursement schemes can be developed, it may be difficult to increase the tax level.

It is far beyond the scope of this article to develop new green tax models. We limit ourselves to suggest that future environmental policy research on green taxation pays more attention to the necessity of reimbursement, and in particular the necessity of reimbursement schemes which do not redistribute within producer communities. Clearly, there is a great need of research on this issue. For advocates of green taxation, the future force of the approach does not lie in further technical refinement of the tax model itself, but in the ability to develop reimbursement schemes which do not redistribute within producer communities and thus decrease industrial opposition. It may well turn out that in some branches, green taxation with reimbursement cannot be implemented without causing redistribution within them. In such case other environmental measures, such as tradable pollution permits, should be considered. 


\section{LITERATURE}

Andersen, M.S. (1994a), Governance by Green Taxes: Making Pollution Prevention Pay, Manchester: Manchester University Press.

Andersen, M. S., Dengsøe, N. and Pedersen, A.B. 2001, An Evaluation of the Impact of Green Taxes in the Nordic countries, Copenhagen: Nordic Council of Ministers.

Baumol, W.J. and Oates, W.E. (1988), The Theory of Environmental Policy, 2. ed., New York: Cambridge University Press.

Baumol, W.J. and W.E. Oates (1971), The Use of Standards and Prices for Protection of the Environment, Swedish Journal of Economics, 73, 1, 42-54.

Boom, J. and Svendsen, G.T. (2000): 'International Emission Trading Systems: Trade Level and Political Acceptability.' JITE (Journal of Instititutional and Theoretical Economics), 4, 548-66.

Buchanan, J.M. and G. Tullock (1975), Polluters' Profits and Political Response: Direct Controls Versus Taxes, The American Economic Review, 65, 139-47.

CDI (1992), Sådan beregnes $\mathrm{CO}_{2}$-afgiften. Copenhagen: Confederation of Danish Industries.

Christiansen, P.M. (1997), Parliaments and Organized Interests in Denmark and Norway, Århus: Department of Political Science, University of Aarhus, Denmark.

Daugbjerg, C. (1995), 'Er miljøpolitik teknik eller politik? En komparativ analyse af miljøpolitik i den svenske og danske landbrugssektor', Nordisk Administrativt Tidsskrift, 76, 1, 33-47.

Daugbjerg, C. (1998a), 'Linking Policy Networks and Environmental Policies: Nitrate Policy Making in Denmark and Sweden 1970-1995', Public Administration, vol. 76, no. 2, 275-94.

Daugbjerg, C. (1998b) Policy Networks under Pressure: Pollution Control, Policy Reforms and the Power of Farmers. Aldershot: Ashgate Publishing.

Daugbjerg, C. (1998c), 'Power and Policy Design: A Comparison of Green Taxation in Scandinavian Agriculture' Scandinavian Political Studies, vol. 21, no 3.

Daugbjerg, C. (1999), 'The Nature of Environmental Policy Making: A Comparison of Danish and Swedish Agri-Environmental Policy', in M. Joas and A.-S. Hermanson (eds), The Nordic Environments: Comparing Political, Administrative, and Policy Aspects, Aldershot: Ashgate.

Daugbjerg, Carsten (2001), "Designing policy change in institutionalised policy networks", e-book (cd-rom): Proceedings from the COST E 19 Seminar: National Forest Programmes: Social and Political Context, Madrid 18-21 October 2000, pp 115-124.

Daugbjerg, Carsten og Gert Tinggaard Svendsen (2001), Green Taxation in Question: Politics and Efficiency in Environmental Regulation, Basingstoke: Palgrave.

Doern, G.B. and R.W. Phidd (1983), Canadian public policy: ideas, structure, process. Toronto: Methuen.

Elmore, R.F. (1987), 'Instruments and strategy in public policy', Policy Studies Review, 7, 1, 174-86.

Energiministeriet (1990), Energi 2000. Handlingsplan for en baredygtig udviklling, Copenhagen.

Enevoldsen, Martin (2000), 'Industrial Energy Efficiency' in A.P. Mol, V. Lauber and J.D Liefferink (eds), The Voluntary Approach to Environmental Policy: Joint 
Environmental Policy-Making in Europe, Oxford: Oxford University Press, pp. 62-104.

Folden, M.M. et al. (1993), $\mathrm{CO}_{2}$-afgiften $i$ modvind - en analyse af interesseorganisationers mulighed for deltagelse og herunder brug af magt $i$ den politiske beslutningsproces $i$ Danmark, Roskilde: Roskilde Universitetscenter.

Hood, C. (1983), The tools of government. London: Macmillan.

Howe, C.W. (1994), 'Taxes Versus Tradable Discharge Permits: A Review in the Light of the U.S. and European Experience', Environmental and Resource Economics, 4, pp. 151-69.

Howlett, M. and M. Ramesh (1994), 'Patterns of policy instrument choice: policy styles, policy learning and the privatization experience', Policy Studies Review, $12,1 / 2,3-24$.

Kahneman, D., J.L. Knetsch and R.T. Thaler (1991), »Anomalies. The Endowment Effect, Loss Aversion and Status Qou Bias«. Journal of Economic Perspectives, vol.5(1), 193-206.

Kahneman, D. and A. Tversky, (1979), »Prospect Theory: An Analysis of Decisions Under Risk«. Econometrica, vol.47, 263-91.

Kasa, S. (1999), Social and political barriers to green tax reform. The case of $\mathrm{CO}_{2}-$ taxes in Norway, Oslo: CICERO, forthcoming in Environmental Politics.

Klaassen, G. and A. Nentjes (1997), 'Sulfur Trading Under the 1990 CAAA in the US: An Assessment of First Experiences.' JITE (Journal of Institutional and Theoretical Economics), 2, 384-410.

Leone, R.A. (1986), Who Profits: Winners and Losers and Government Regulation, New York: Basic Books.

Linder, Stephen, H. and B.G. Peters (1989), 'Instruments of government: perceptions and contexts', Journal of Public Policy, 9, 1, 35-58.

Lundqvist, L.J. (1996), 'Sweden' 257-336 in P.M. Christiansen (ed.) Governing the Environment: Politics, Policy and Organization in the Nordic Countries, Nord 1996:5, Copenhagen: Nordisk Ministerråd.

Majone, G. (1989), The Evidence, Argument \& Persuasion in the Policy Process. New Haven: Yale University Press.

Naturvårdsverket (1997), Miljöskatter $i$ Sverige - ekonomiska styrmedel $i$ miljöpolitiken, Stockholm: Naturvårdsverkets Förlag. Also available in english: Environmental taxes in Sweden - economic instruments of environmental policy.

OECD (1997), Evaluating Economic Instruments for Environmental Policy, Paris: OECD Publications.

Olson, M. (1965), The Logic of Collective Action, Cambridge: Cambridge University Press.

Pearce, D., A. Markandya and E.B. Barbier (1989), Blueprint for a Green Economy. London: Earthscan Publications.

Pearce, D.W. and R.K. Turner (1990), Economics of Natural Resources and the Environment. New York and London: Harvester Wheatsheaf.

Pigou, A.C. (1932 [1920]) The Economics of Welfare. London: Macmillan and co.

Salamon, L.M. (1981), 'Rethinking Public Management: Third-Party Government and The Changing Forms of Government Action,' Public Policy, 29, 255-75.

Skatteministeren (1995), 'Lovforslag nr. L 182, 1995,: Forslag til lov om afgift af bekæmpningsmidler,' in Folketingstidende 1994-95, Tillæg A. 
SOU (1989), Ekonomiska styrmedel i miljöpolitiken. Energi och trafik (no. 1989:83), Stockholm: Almänna Förlaget.

Svendsen, G.T. (1998): Public Choice and Environmental Regulation: Tradable Permit Systems in United States and $\mathrm{CO}_{2}$ Taxation in Europe. Edward Elgar, Cheltenham, UK.

Svendsen, G.T., C. Daugbjerg, L. Hjøllund and A.B. Pedersen (2001), 'Consumers, Industrialists and the Political Economy of Green Taxation: $\mathrm{CO}_{2}$ Taxation in the OECD'. Energy Policy, 29 (6), 489-97.

Swedish Government (1990), Regeringens proposition 1989/90: 111. Om reformerad mervärdeskatt m.m., Stockholm.

Tenfjord, A.-P. (1995), $\mathrm{CO}_{2}$-saka: Økonomisk interessepolitikk og miljфpolitiske målsetjingar. Rapport 9507, Bergen: LOS-Senteret.

Tietenberg, T.H. (1985), Emissions Trading: An Exercise in Reforming Pollution Policy, Washington, D.C.: Resources for the Future.

Thaler, R. (1980), »Toward a positive theory of consumer choice«. Journal of Economic Behavior and Organization, vol.1, 39-60.

VROM (1998), 'Green Taxes: Questions and Answers', http://www.minvrom.nl (transcript 12 May 1999).

Weaver, R.K. (1986), 'The Politics of Blame Avoidance', Journal of Public Policy, vol. 6 , no. 4, 371-98. 